\title{
e-ISSN $1983-0572$ \\ Infestation of Palm Trees by Triatomines (Hemiptera: Reduviidae) in the State of Bahia, Brazil
}

\author{
Rodrigo Gurgel-Gonçalves ${ }^{\circledR}{ }^{\bowtie}$, Gilmar Ribeiro Júnior² \& Eraldo Medeiros da Costa Neto $^{3}$
}

1. Laboratório de Parasitologia Médica e Biologia de Vetores, Faculdade de Medicina, Universidade de Brasília, e-mail: rgurgel@unb.br (Autor para correspondência $^{\bowtie}$ ). 2. Centro de Pesquisas Gonçalo Moniz (CPqGM), FIOCRUZ, Salvador, Bahia, e-mail: gilmarribeirojr@gmail.com. 3. Universidade Estadual de Feira de Santana, Bahia, e-mail: eraldont@hotmail.com.

\section{EntomoBrasilis 5 (3): 227-231 (2012)}

\begin{abstract}
Palm trees play important roles as breeding and foraging habitats for sylvatic triatomines, vectors of Chagas disease. The occurrence of triatomines in peridomestic palm trees may increase the risk of invasion in households and should therefore be considered to develop prevention strategies. In order to investigate the infestation of palm trees by triatomines in the state of Bahia and to determine their natural infection with Trypanosoma spp., we sampled 183 palms in 12 municipalities between 2006 and 2011 using manual capture and/or mouse-baited adhesive traps. Triatomines were detected in 79 palms (43\%) such as Copernicia prunifera, (Mart.) Becc., Mauritia flexuosa L. and Attalea spp. (Attalea burretiana Bondar or Attalea salvadorensis Glassman). In other palm species (Syagrus coronata (Mill) H.E. Moore, Attalea funifera Mart ex. Spreng, and Elaeis guineensis Jacq) triatomines were not detected. Rhodnius neglectus Lent, Triatoma sordida (Stål), and Triatoma pseudomaculata Corrêa \& Espínola occurred in C. prunifera along the São Francisco River. In western Bahia, R. neglectus and Psammolestes tertius Lent \& Jurberg were detected in M. flexuosa, while Triatoma tibiamaculata (Pinto) occurred in Attalea sp. in urban areas of Salvador on the coast of Bahia. Overall, 180 triatomines were captured, mainly $R$. neglectus. T. tibiamaculata had the highest rate of natural infection (61\%). The results indicate that at least three species of palms are suitable habitats for triatomines in the state of Bahia and occur in peridomestic environment, what may enhance the probability of triatomine invasion into houses.
\end{abstract}

Keywords: Arecaceae; Chagas disease; Entomological surveillance; Triatominae.

\section{Infestação de Palmeiras por Triatomíneos (Hemiptera: Reduviidae) no Estado da Bahia, Brasil}

Resumo. As palmeiras desempenham papéis importantes como habitats de reprodução e alimentação para triatomíneos silvestres, vetores da doença de Chagas. A ocorrência de triatomíneos em palmeiras peridomiciliares pode aumentar o risco de invasão desses insetos em domicílios e deve ser considerada para desenvolver estratégias de prevenção. Com objetivo de investigar a infestação de palmeiras por triatomíneos no Estado da Bahia e determinar a infecção natural desses insetos por Trypanosoma spp., foram amostradas 183 palmeiras em 12 municípios entre 2006 e 2011 utilizando captura manual e/ou armadilhas adesivas iscadas com camundongos. Os triatomíneos foram detectados em 79 palmeiras (43\%) das espécies Copernicia prunifera (Mart.) Becc., Mauritia flexuosa L. e Attalea spp. (Attalea burretiana Bondar ou Attalea salvadorensis Glassman). Em outras espécies de palmeiras (Syagrus coronata (Mill) H.E. Moore, Attalea funifera Mart ex. Spreng e Elaeis guineensis Jacq) não foram detectados triatomíneos. Rhodnius neglectus Lent, Triatoma sordida (Stål), e Triatoma pseudomaculata Corrêa \& Espínola ocorreram em C. prunifera ao longo do rio São Francisco. No extremo oeste da Bahia, R. neglectus e Psammolestes tertius Lent \& Jurberg foram detectados em $M$. flexuosa, enquanto Triatoma tibiamaculata (Pinto) ocorreu em Attalea sp. em áreas urbanas de Salvador. No total, 180 triatomíneos foram capturados, principalmente $R$. neglectus. A maior taxa de infecção natural (61\%) foi observada em T. tibiamaculata. Os resultados indicam que pelo menos três espécies de palmeiras são habitats favoráveis para triatomíneos no estado da Bahia e ocorrem no ambiente peridomiciliar, o que pode aumentar a probabilidade de invasão de triatomíneos nas casas.

Palavras-Chave: Arecaceae; Doença de Chagas; Triatominae; Vigilância entomológica.

$\mathbf{P}$ alm trees play important roles as breeding and foraging habitats for sylvatic triatomines, vectors of Chagas disease, especially for Rhodnius Stål species (LENT \& WYGODZINSKY 1979). The distribution of these triatomines in Latin America coincides with the distribution of palms (GAunt \& Miles 2000; ABad-Franch et al. 2009; Gurgel-Gonçalves \& Cuba 2009).

In Brazil, high rates of palm infestation by triatomines have been reported (BARRetTo et al. 1969; Miles et al. 1983; Diotaiuti \& Dias 1984; Pinto \& Bento 1986; Bento et al. 1992; Teixeira et al. 2001; GuRgel-Gonçalves et al. 2004a; SARQuis et al. 2004; Dias et al. 2008; ABAD-Franch et al. 2009; Dias et al. 2010). Moreover, palm trees provide shelter and food for several vertebrates; some of them often sleep and nest in the crown, which favors the maintenance of a steady blood supply for triatomines in this environment (Teixeira et al. 2001; Gurgel-Gonçalves \& Cuba
2007; Dias et al. 2010). Thus, palms have been considered as an ecological indicator of areas where enzootic Trypanosoma cruzi Chagas transmission cycles probably occur (Romaña et al. 1999; ABAD-Franch et al. 2010; GURGEL-GonÇALVEs et al. 2012a).

The state of Bahia has the highest triatomine species richness in Brazil (Gurgel-GonçALVEs et al. 2012b). Additionally, at least 59 native palm tree species occur in Bahia (LoRENzI et al. 2004). Some triatomine species recorded in domiciles in Bahia, such as Triatoma sordida (Stål) (CARCAVALlo et al. 1998) and Rhodnius neglectus Lent (GURGEL-GONÇALVES \& CUBA 2009), have been also detected in palms from other Brazilian regions suggesting that the origin of some specimens collected inside houses in Bahia is related to the presence of palm trees. In addition, triatomines infected with $T$. cruzi, particularly Triatoma tibiamaculata (Pinto), have been frequently found near urban forest remnants 
where palm trees are present in the capital city, Salvador (DIASLima \& Sherlock 2000; Santana et al. 2011). The occurrence of triatomines in peridomestic palm trees may increase the risk of invasion in households and should therefore be considered to develop prevention strategies. This study aims to investigate the infestation of palm trees by triatomines in the state of Bahia and to determine their natural infection with Trypanosoma spp. These data expand the knowledge of triatomine bugs from Bahia, thus contributing to the design of improved strategies for Chagas disease vector surveillance.

\section{MATERIAL AND METHODS}

We sampled 183 palms in 12 municipalities in State of Bahia, Brazil, between 2006 and 2011. The sample covered almost all the mesoregions of the state, and prioritized palm genera with wide geographical distribution (Attalea, Copernicia, Elaeis, Mauritia, Syagrus) (Figure 1). The identification of palm species was based on LORENZI et al. (2004). Palm trees were distributed between 10 and $500 \mathrm{~m}$ away from houses. Sampling was carried out along linear transects (40 to $500 \mathrm{~m}$ ) with equally spaced points (10 m). At each point, the nearest palm tree was sampled.

Two sampling methods of triatomines were used: manual capture and mouse-baited adhesive traps, similar to those described by NoIREAU et al. (2002). The collection of insects was done with prior licensing from Instituto Chico Mendes de Conservação da Biodiversidade (ICMBio). Ladders and ropes were used to reach the palm tree crowns, from where organic matter, vegetation and abandoned nests were collected and placed into plastic bags. This material was then brought down to the ground and placed over a white cloth to facilitate triatomine search (GURGEL-GonçALVES et al. 2003). Additionally, we performed an active search of bugs between the bases of the leaves with a tweezer. This method was used for sampling Mauritia flexuosa L., Copernicia prunifera (Mill) H.E. Moore, and Syagrus coronata (Mart.) Becc. In the case of Attalea funifera Mart ex. Spreng we did only active search of bugs between the bases of the leaves and fibers.

Research was approved by the ethics committee on animal use at the State University of Feira de Santana. One to six traps were placed at the base of the leaves on opposite sides of palms. Traps were operated for approximately 16 hours, from sunset until the following morning. Elaeis guineensis Jacq. (114 trapnights), Attalea palms (Attalea burretiana Bondar and Attalea salvadorensis Glassman) (120 trap-nights), C. prunifera (45 trap-nights), and $S$. coronata (50 trap-nights) were sampled using this method. Additionally, 16 bromeliads located on the palms or trees near the palms were sampled using the traps (20 trap-nights).

Triatomines were identified to the species level according to LENT \& WYGODZINSKY (1979). Trypanosoma spp. infection was determined by examination of fresh feces obtained by abdominal compression of the triatomine bugs. Parasites were morphologically identified by observation under a light microscope of Giemsa-stained insect feces (Cuba Cuba 1998).

\section{RESULTS}

Triatomines were detected in C. prunifera, M. flexuosa and A. burretiana/A. salvadorensis (Table 1). Among the 183 palms sampled, 79 (43\%) were infested; 180 triatomines were collected (average of 2.3 triatomines per palm). $R$. neglectus, $T$. sordida, and Triatoma pseudomaculata Corrêa \& Espínola occurred in $C$. prunifera along the São Francisco river. In western Bahia, $R$. neglectus and Psammolestes tertius Lent \& Jurberg were detected in $M$. flexuosa, while T. tibiamaculata occurred in Attalea spp. in urban areas of Salvador on the coast of Bahia (Table 1). $R$. neglectus was the most common species in palm trees, representing $66 \%$ of the triatomines captured. In the municipality of Ibotirama, where two methods were applied simultaneously to collect triatomines in C. prunifera, the efficacy of manual capture (palm infestation $=65 \%$ and number of insects/infested palm $=$ 3.3) was higher than that obtained using mouse-baited adhesive traps (27\% and 1.25, respectively). No bugs were detected in 16 bromeliads sampled.

Thirteen of the 93 triatomines examined were infected with Trypanosoma spp. in C. prunifera, M. flexuosa and Attalea spp. (Table 1). T. tibiamaculata had the highest rate of natural infection $(61 \%)$. The phenotypic identification of the parasites revealed flagellates morphologically similar to T. cruzi in palms from Ibotirama and Salvador, but in São Desidério we identified parasites morphologically similar to $T$. rangeli Tejera.

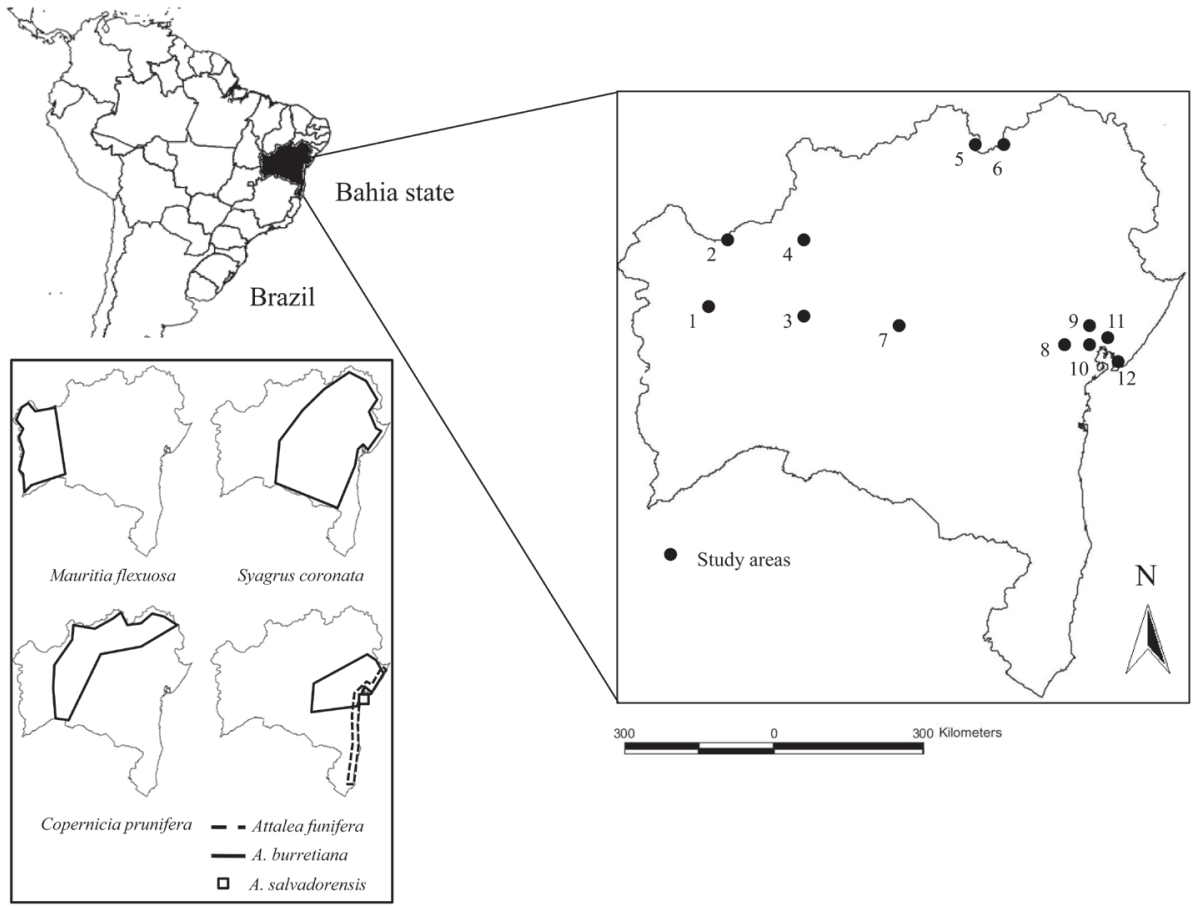

Figure 1. Study areas in the state of Bahia. The geographical distribution of palm species sampled in the study is also presented (modified from LoRENZI et al. 2004). Municipalities according to mesoregions of the state: Western Bahia: (1) São Desidério and (2) Santa Rita de Cássia; São Francisco Valley: (3) Ibotirama, (4) Xique-Xique, (5) Juazeiro and (6) Curaçá; Central South Bahia: (7) Seabra; Central North Bahia: (8) Santa Terezinha and (9) Conceição do Jacuípe; Metropolitan Salvador: (10) São Félix, (11) Cachoeira and (12) Salvador. The geographical distribution of the African palm Elaeis guineensis was not presented in Bahia, despite being common in the Recôncavo baiano region. 
Table 1. Entomological indices of triatomines in palm tree species sampled in 12 municipalities, Bahia, Brazil.

\begin{tabular}{|c|c|c|c|c|c|c|c|c|c|}
\hline Palm species & Municipality & $\begin{array}{l}\text { N palms } \\
\text { sampled }\end{array}$ & $\begin{array}{l}\text { Distance to } \\
\text { the nearest } \\
\text { domicile (m) }\end{array}$ & $\begin{array}{l}\text { Triatomine } \\
\text { species }\end{array}$ & $\begin{array}{c}\text { Infested } \\
\text { palms } \\
(\%)\end{array}$ & $\begin{array}{l}\text { Insects } \\
\text { colected }\end{array}$ & $\begin{array}{c}\text { Insects/ } \\
\text { infested } \\
\text { palm }\end{array}$ & $\begin{array}{l}\text { Insects } \\
\text { examined } \\
(\%)\end{array}$ & $\begin{array}{c}\text { Insects } \\
\text { infected } \\
(\%)\end{array}$ \\
\hline \multirow{3}{*}{$\begin{array}{l}\text { Mauritia } \\
\text { flexuosa }\end{array}$} & \multirow{2}{*}{$\begin{array}{c}\text { São } \\
\text { Desidério }\end{array}$} & $4^{1}$ & 200 & Rhodnius neglectus & $3(75)$ & 15 & 5 & $9(60)$ & $1(11)^{3}$ \\
\hline & & & & $\begin{array}{c}\text { Psammolestes } \\
\text { tertius }\end{array}$ & $2(50)$ & 32 & 16 & - & - \\
\hline & $\begin{array}{l}\text { Santa Rita de } \\
\text { Cássia }\end{array}$ & $11^{1}$ & 20 & R. neglectus & $4(36)$ & 16 & 4 & $2(12.5)$ & $o(0)$ \\
\hline \multirow{6}{*}{$\begin{array}{c}\text { Copernicia } \\
\text { prunifera }\end{array}$} & \multirow{2}{*}{ Ibotirama } & $23^{1,2}$ & 250 & R. neglectus & $13(56)$ & 50 & 4 & $35(70)$ & $1(3)^{4}$ \\
\hline & & & & $\begin{array}{l}\text { Triatoma } \\
\text { sordida }\end{array}$ & $7(30)$ & 10 & 1.4 & $7(70)$ & o (o) \\
\hline & Xique Xique & $10^{1}$ & 300 & R. neglectus & $6(60)$ & 17 & 2.8 & $8(47)$ & o (o) \\
\hline & Juazeiro & $5^{1}$ & 30 & R. neglectus & $4(80)$ & 17 & 4.2 & $12(70.6)$ & o (o) \\
\hline & \multirow{2}{*}{ Curaçá } & $10^{1}$ & 50 & R. neglectus & $2(20)$ & 4 & 2 & $2(50)$ & o (o) \\
\hline & & & & $\begin{array}{c}\text { Triatoma } \\
\text { pseudomaculata }\end{array}$ & $1(10)$ & 1 & 1 & - & - \\
\hline \multirow{2}{*}{$\begin{array}{l}\text { Syagrus } \\
\text { coronata }\end{array}$} & Seabra & $10^{1}$ & 500 & - & $\mathrm{o}(\mathrm{o})$ & $\mathrm{O}$ & - & - & - \\
\hline & $\begin{array}{c}\text { Santa } \\
\text { Terezinha }\end{array}$ & $5 \mathrm{O}^{2}$ & 10 & - & o (o) & o & - & - & - \\
\hline \multirow{2}{*}{$\begin{array}{c}\text { Elaeis } \\
\text { guineensis }\end{array}$} & $\begin{array}{l}\text { Conceição do } \\
\text { Jacuípe }\end{array}$ & $16^{2}$ & 250 & - & o (o) & o & - & - & - \\
\hline & São Félix & $14^{2}$ & 30 & - & o (o) & o & - & - & - \\
\hline Attalea funifera & Cachoeira & $10^{1}$ & 500 & - & o (o) & o & - & - & - \\
\hline $\begin{array}{l}\text { A. burretiana/ } \\
\text { A. salvadorensis }\end{array}$ & Salvador & $2 O^{2}$ & 50 & $\begin{array}{c}\text { Triatoma } \\
\text { tibiamaculata }\end{array}$ & $2(10)$ & 18 & 9 & $18(100)$ & $11(61)^{4}$ \\
\hline Total & & 183 & 200 & & $79(43)$ & 180 & 2.3 & $93(51.7)$ & $13(14)$ \\
\hline
\end{tabular}

${ }^{1}$ Manual capture, ${ }^{2}$ Mouse-baited adhesive traps, ${ }^{3}$ Trypanosoma rangeli, ${ }^{4}$ Trypanosoma cruzi.

\section{DISCUSSION}

This paper lists the palm tree species associated with triatomines in the state of Bahia, Brazil. The results indicate that at least three widely distributed species of palms are favorable habitats for the maintenance of $R$. neglectus, T. sordida and T. pseudomaculata populations in western Bahia and the São Francisco valley, and $T$. tibiamaculata populations in the metropolitan region of Salvador. Specimens infected with parasites morphologically similar to T. cruzi were detected in palm trees from Salvador and Ibotirama; their proximity to houses may maintain the risk for vector-borne transmission of Chagas disease, as suggested in other regions of Brazil (Miles et al. 1983; SARquis et al. 2004; ABAD-Franch et al. 2009).

The occurrence of $R$. neglectus in $M$. flexuosa and C. prunifera palms in the state of Bahia was expected, as the species had been recorded in these palms in other regions of Brazil (BENTO et al. 1992; Carcavallo et al. 1998; GuRgel-GonÇAlves et al. 2003, 2004a; ABAD-FrANCH et al. 2009). The results show that $R$. neglectus is more common in palms of western Bahia and the São Francisco valley. The geographical distribution of this species in these areas had already been predicted based on ecological niche modeling (BATISTA \& GURGEL-GonÇALVES 2009), and data from the present study confirm these predictions. Additionally, specimens of $R$. neglectus have been collected in domiciles of northwestern Bahia (Silveira et al. 1984). Adult specimens may invade houses by flying from infested peridomestic palms (CASTRo et al. 2010, GURGEL-Gonçalves et al. 2012a) or due to passive transport of insects from palm material used in building peridomestic structures.

In addition to $R$. neglectus, $T$. pseudomaculata and $T$. sordida were also recorded in C. prunifera, and P. tertius in M. flexuosa. The presence of these triatomine species in palm trees may be associated with the occurrence of bird nests (BARRETTO \& Carvalheiro 1968; Barretto et al. 1969; Gurgel-Gonçalves \& CuBA 2007). Although T. pseudomaculata and T. sordida preferably live under bark, they have also been caught in bird nests (CARCAVAllo et al. 1998). In this study, we show for the first time the co-occurrence of $R$. neglectus and $T$. sordida in the palm C. prunifera. In the municipality of Ibotirama, 5 out 13 infested palms were occupied by both species.

The results also show that Attalea palms (A. burretiana and/or A. salvadorensis) are infested by $T$. tibiamaculata in urban areas of Salvador. This species is predominantly sylvatic, occurring naturally in shelters of marsupials and rodents, including bromeliads and palms (CARCAVAllo et al. 1998). However, its presence in domestic environment has been reported in state of Bahia (Dias-Lima \& Sherlock 2000; Santana et al. 2011).

In the present study, triatomines were not detected in S. coronata palms. However, this palm has been described as habitat of T. sordida and Rhodnius nasutus Stål in Iraquara, state of Bahia (VEnÂNcIo 2010). Considering the wide geographical distribution of $S$. coronata in Bahia, there is a need to study a more representative sample of this species to determine its role in the maintenance of triatomine bugs. We did not observe nesting birds or mammals in E. guineensis, which might reduce infestation probabilities. In the case of $A$. funifera, the few specimens sampled were young and they also had no evidence of vertebrates in its crowns.

The natural infection rate of $R$. neglectus with flagellates morphologically similar to $T$. cruzi or $T$. rangeli in palm trees obtained in this study (3\%) was low compared to other regions of Brazil (Barretto et al. 1969; Diotaiuti \& Dias 1984; GurgelGonçalves et al. 2004b; ABAD-Franch et al. 2009). However, about half of the specimens captured were not examined because they arrived dead and dried in the laboratory. Recent studies of trypanosomatid detection using molecular tools (GurGeLGONÇALVES et al. 2012a) confirmed the infection of $R$. neglectus specimens from São Desidério with T.rangeli. Unlike R. neglectus, T. tibiamaculata presented a high rate of natural infection with flagellates morphologically similar to T. cruzi. Molecular characterization of parasites from these triatomines confirmed the phenotypic identification. This high natural infection rate 
could be due to the frequent occurrence of many mammals in the crown of Attalea palms (Miles et al. 1983), including species of Didelphis known as natural reservoirs of T. cruzi (RAMIREz et al. 2002; STEINDEL et al. 2008).

In Salvador, human population growth coupled with urbanization has caused the deforestation of the Atlantic forest remnants or a closer contact of the houses with forested areas, where palm trees naturally occur. This may facilitate the invasion of houses by triatomines, which may increase the risk of Chagas disease transmission (DiAs-Lima \& SHERLOCK 2000). In Salvador, the Chagas disease Control Program (PCDCh) asks residents to collect and send suspect specimens to triatomine information posts, where insects are identified and infection by Trypanosoma cruzi ascertained. According to SANTANA et al. (2011), T. tibiamaculata was the species most frequently collected in Salvador between 2006 and 2009; 54\% of all triatomines were collected inside houses and $48.6 \%$ were infected with $T$. cruzi, indicating the risk of vector-borne or oral transmission (DiAs et al. 2006).

In conclusion, our data reinforce the idea that the occurrence of peridomestic palms (as in the case of Attalea spp. in Salvador and $C$. prunifera in Ibotirama) could help define risk situations at the local level (ABAD-FRANCH et al. 2010). Since palms with large amounts of decaying vegetable debris are frequently infested, it has been suggested that cutting down dead leaves and removing epiphytes from palm crowns might help reduce infestation risk (ABAD-Franch et al. 2005, 2010).

\section{ACKNOWLEDGEMENTS}

We thank the health agents of the state of Bahia for their field work assistance and Fábio O. Alves for technical support in collection of triatomines in palm trees. We also thank Nilmara Saturnino de Souza, Karine de Cerqueira Silva Oliveira, Rodrigo Oliveira, and Luiz Rodrigo Lima da Motta for their help in field work and staff of the biotherium of UEFS. Dr. Fernando Abad-Franch and Dr. Fernando Braga Stehling Dias provided insightful comments on the manuscript. Field surveys were financed by FAPESB and CNPq.

\section{REFERENCES}

Abad-Franch, F., G. Ferraz, C. Campos, F.S. Palomeque, M.J. Grijalva, H.M. Aguilar \& M.A. Miles, 2010. Modeling disease vector occurrence when detection is imperfect: Infestation of amazonian palm trees by triatomine bugs at three spatial scales. PLoS Neglected Tropical Diseases, 4: e620.

Abad-Franch, F., F.A. Monteiro, N.O. Jaramillo, R. GurgelGonçalves, F.B.S. Dias \& L. Diotaiuti, 2009. Ecology, evolution and the long-term surveillance of vector-borne Chagas disease: A multi-scale appraisal of the tribe Rhodniini (Triatominae). Acta Tropica, 112: 159-177.

Abad-Franch, F., F.S. Palomeque, V.H.M. Aguilar \& M.A. Miles, 2005. Field ecology of sylvatic Rhodnius populations (Heteroptera, Triatominae): risk factors for palm tree infestation in western Ecuador. Tropical Medicine \& International Health, 10: 1258-1266.

Barretto, M.P. \& J.R. Carvalheiro, 1968. Estudos sobre reservatórios e vectores silvestres do Trypanosoma cruzi: XXVIII: Sobre o encontro de Triatoma sordida, Stal 1859 e Rhodnius nelgectus Lent, 1954 em ninhos de pássaros da família Furnariidae. Revista Brasileira de Biologia, 2: 289293.

Barretto, M.P., D.R.R. Albuquerque \& G.K. Funayama, 1969. Estudos sobre reservatórios e vectores silvestres do Trypanosoma cruzi. XXXVI: Investigação sobre triatomíneos de palmeiras no município de Uberaba, MG, Brasil. Revista Brasileira de Biologia, 29: 577-588.

Batista, T.A. \& R. Gurgel-Gonçalves, 2009. Ecological niche modelling and differentiation between Rhodnius neglectus Lent, 1954, and R. nasutus Stål, 1859 (Hemiptera, Reduviidae,
Triatominae), in Brazil. Memórias do Instituto Oswaldo Cruz, 104: 1165-1170.

Bento, D.N.C., L.M. Farias, M.F. Godoy \& J.F.P. Araújo, 1992. Epidemiologia da doença de Chagas na zona rural do município de Teresina-Piauí, Brasil. Revista da Sociedade Brasileira de Medicina Tropical, 25: 51-58.

Carcavallo, R.U., M.E.F. Rodríguez, R. Salvatella, S.I. Curto de Casas, I. Sherlock, C. Galvão, D.S. Rocha, I. Galíndez Girón, M.A.O. Arocha, A. Martinez, J.A. da Rosa, D.M. Canale, T.H. Farr \& J.M.S. Barata, 1998. Habitat and related fauna, p. 5616oo. In: Carcavallo, R.U., I. Galíndez Girón, J. Jurberg \& H. Lent (Eds.) Atlas of Chagas Disease vectors in Americas Vol. II, Fiocruz, Rio de Janeiro, 1217p.

Castro, M.C., T.V. Barrett, W.S. Santos, F. Abad-Franch \& J.A. Rafael, 2010. Attraction of Chagas disease vectors (Triatominae) to artificial light sources in the canopy of primary Amazon rainforest. Memórias do Instituto Oswaldo Cruz, 105: 1061-1064.

Cuba Cuba, C.A, 1998. Revisión de los aspectos biológicos y diagnósticos del Trypanosoma (Herpetosoma) rangeli. Revista da Sociedade Brasileira de Medicina Tropical, 31: 207-220.

Dias, J.P., C. Bastos, E.G. de Araújo, A.V. Mascarenhas, E. Netto, F. Grassi , M. Silva , E. Tatto, J. Mendonça, R.F. de Araújo, M.T. Obara, M.P. Silva, C. Furuchó \& R. Aras, 2006. Outbreak of acute Chagas disease occurred in the state of Bahia, Brazil. Revista da Sociedade Brasileira de Medicina Tropical, 39: 135-137.

Dias, F.B.S., C.M. Bezerra, E.M.M. Machado, C. Casanova \& L. Diotaiuti, 2008. Ecological aspects of Rhodnius nasutus Stål, 1859 (Hemiptera: Reduviidae: Triatominae) in palms of the Chapada do Araripe in Ceará, Brazil. Memórias do Instituto Oswaldo Cruz, 103: 824-30.

Dias, F.B.S., M. Quartier, C.A. Romaña, L. Diotaiuti \& M. Harry, 2010. Tamandua tetradactyla Linnaeus, 1758 (Myrmecophagidae) and Rhodnius robustus Larrousse, 1927 (Triatominae) infection focus by Trypanosoma rangeli Tejera, 1920 (Trypanosomatidae) in Attalea phalerata Mart. ex Spreng (Arecaceae) palm tree in the Brazilian Amazon. Infection Genetics and Evolution, 10: 1278-1281.

Dias-Lima, A.G. \& I.A. Sherlock, 2000. Sylvatic vectors invading houses and the risk of emergence of cases of Chagas disease in Salvador, state of Bahia, Northeast Brazil. Memórias do Instituto Oswaldo Cruz, 95: 611-613.

Diotaiuti, L. \& J.C.P. Dias, 1984. Ocorrência e biologia de Rhodnius neglectus, Lent, 1954 em macaubeiras da periferia de Belo Horizonte, Minas Gerais. Memórias do Instituto Oswaldo Cruz, 79: 293-301.

Gaunt, M.F. \& M.A. Miles, 2000. The ecotopes and evolution of triatomine bugs (Triatominae) and their associated trypanosomes. Memórias do Instituto Oswaldo Cruz, 95: 557565 .

Gurgel-Gonçalves, R. \& C.A.C. Cuba, 2007. Estrutura de populações de Rhodnius neglectus (Lent) e Psammolestes tertius (Lent \& Jurberg) (Hemiptera, Reduviidae) em ninhos de pássaros (Furnariidae) presentes na palmeira Mauritia flexuosa no Distrito Federal, Brasil. Revista Brasileira de Zoologia, 24: 157-163.

Gurgel-Gonçalves, R. \& C.A.C. Cuba, 2009. Predicting the potential geographical distribution of Rhodnius neglectus (Hemiptera, Reduviidae) based on ecological niche modeling. Journal of Medical Entomology, 46: 952-960.

Gurgel-Gonçalves, R., C. Cura, A.G. Schijman, C.A.C. Cuba, 2012a. Infestation of Mauritia flexuosa palms by triatomines (Hemiptera: Reduviidae), vectors of Trypanosoma cruzi and Trypanosoma rangeli in the Brazilian savanna. Acta Tropica, 121: 105-111.

Gurgel-Gonçalves, R., M.A. Duarte, E.D. Ramalho, C.A. Romaña \& C.A.C. Cuba, 2004a. Distribuição espacial de populações de Triatominae (Hemiptera, Reduviidae) em palmeiras da espécie Mauritia flexuosa no Distrito Federal, Brasil. Revista 
da Sociedade Brasileira de Medicina Tropical, 37: 241-247.

Gurgel-Gonçalves, R., C. Galvão, J. Costa, A.T. Peterson, 2012b. Geographic distribution of Chagas disease vectors in Brazil based on ecological niche modeling. Journal of Tropical Medicine, 2012: 1-15.

Gurgel-Gonçalves, R., A.R.T. Palma, M.N.A. Menezes, R.N. Leite \& C.A.C. Cuba, 2003. Sampling Rhodnius neglectus (Triatominae) in Mauritia flexuosa palm trees (Arecaceae): a field study in the Brazilian Savanna. Medical and Veterinary Entomology, 17: 347-349.

Gurgel-Gonçalves, R., E.D. Ramalho, M.A. Duarte, A.R.T. Palma, F. Abad-Franch, J.C. Carranza \& C.A.C. Cuba, 2004b. Enzootic transmission of Trypanosoma cruzi and T. rangeli in the Federal District of Brazil. Revista do Instituto de Medicina Tropical de São Paulo, 46: 323-330.

Lent, H. \& P. Wygodzinsky, 1979. Revision of the Triatominae (Hemiptera, Reduviidae), and their significance as vectors of Chagas Disease. Bulletin of the American Museum of Natural History, 163: 520-529.

Lorenzi, H, H.M. Souza, J.T.M. Costa, L.S.C. Cerqueira \& E. Ferreira, 2004. Palmeiras brasileiras e exóticas cultivadas. Nova Odessa, Instituto Plantarum, 432p.

Miles, M.A., J.R. Arias \& A.A. de Souza, 1983. Chagas Disease in Amazom basin: V Periurban palms and habitats of Rhodnius robustus and Rhodnius pictipes - triatomine vectors of Chagas Disease. Memórias do Instituto Oswaldo Cruz, 78: 391-398.

Noireau, F., F. Abad-Franch, S.A.S. Valente, A. Dias-Lima, C.M. Lopes, V. Cunha, V.C. Valente, F.S. Palomeque, C.J. CarvalhoPinto, I. Sherlock, M. Aguilar, M. Steindel, E.C. Grisard \& J. Jurberg, 2002. Trapping triatomine in sylvatic habitats. Memórias do Instituto Oswaldo Cruz, 97: 61-63.

Pinto, A.S. \& D.N.C. Bento, 1986. The palm tree Copernicia cerifera (Carnaúba) as an ecotope of Rhodnius nasutus in rural areas of the state of Piauí northeastern Brazil. Revista da Sociedade Brasileira de Medicina Tropical, 19: 243-245.

Ramirez, L.E., E. Lages-Silva, F. Alvarenga-Franco, A. Matos, N. Vargas, O. Fernandes \& B. Zingales, 2002. High prevalence of Trypanosoma rangeli and Trypanosoma cruzi in opossums and triatomids in a formerly-endemic area of Chagas disease in Southeast Brazil. Acta Tropica, 84: 189-198.
Romaña, C.A., J.C.N. Pizarro, E. Rodas \& E. Guilbert, 1999. Palm trees as ecological indicator of risk areas for Chagas disease. Transactions of the Royal Society of Tropical Medicine and Hygiene, 93: 594-595.

Santana, K.S., M.E. Bavia, A.D. Lima, I.C. Guimarães, E.S. Soares, M.M. Silva, J. Mendonça \& M.S. Martin, 2011. Spatial distribution of triatomines (Reduviidae: Triatominae) in urban areas of the city of Salvador, Bahia, Brazil. Geospatial Health, 5: 199-203.

Sarquis, O., J. Borges-Pereira, J.R. MacCord, T.F. Gomes, P.H. Cabello \& M.M. Lima, 2004. Epidemiology of Chagas disease in Jaguaruana, Ceará. I. Presence of triatomines and index of Trypanosoma cruzi infection in four localities of a rural area. Memórias do Instituto Oswaldo Cruz, 99: 263-270.

Silveira, A.C., V.R. Feitosa \& R. Borges, 1984. Distribuição de triatomíneos capturados no ambiente domiciliar, no período de 1975/83, Brasil. Revista Brasileira de Malariologia e Doenças Tropicais, 39: 15-312.

Steindel, M, L.K. Pacheco, D. Scholl, M. Soares, M.H. Moraes, I. Eger, C. Kosmann, T.C. Sincero, P.H. Stoco, S.M. Murta, C.J. Carvalho-Pinto \& E.C. Grisard, 2008. Characterization of Trypanosoma cruzi isolated from humans, vectors, and animal reservoirs following an outbreak of acute human Chagas disease in Santa Catarina State, Brazil. Diagnostic Microbiology and Infectious Disease, 60: 25-32.

Teixeira, A.R.L., P.S. Monteiro, J.M. Rebelo, E.R. Arganaraz, D. Vieira, L. Lauria-Pires, R. Nascimento, C.A. Venexat, A.R. Silva, S.K. Ault \& J.M. Costa, 2001. Emerging Chagas disease: trophic network and cycle of transmission of Trypanosoma cruzi from palm trees in the Amazon. Emerging Infectious Diseases, 7: 100-112.

Venâncio, A.F., 2010. Subsídios para a gestão do risco em Saúde Pública: o caso da tripanossomíase americana. Tese (Doutorado em Políticas Públicas e Gestão Ambiental) Universidade de Brasília. 340p.

\section{Recebido em: 12/o6/2012}

Aceito em: 20/12/2012

\section{Como citar este artigo:}

Gurgel-Gonçalves, R., G. Ribeiro Júnior \& E.M. Costa Neto, 2012. Infestation of Palm Trees by Triatomines (Hemiptera: Reduviidae) in the State of Bahia, Brazil. EntomoBrasilis, 5(3): 227-231.

Acessível em: http://www.periodico.ebras.bio.br/ojs/index.php/ebras/article/view/253

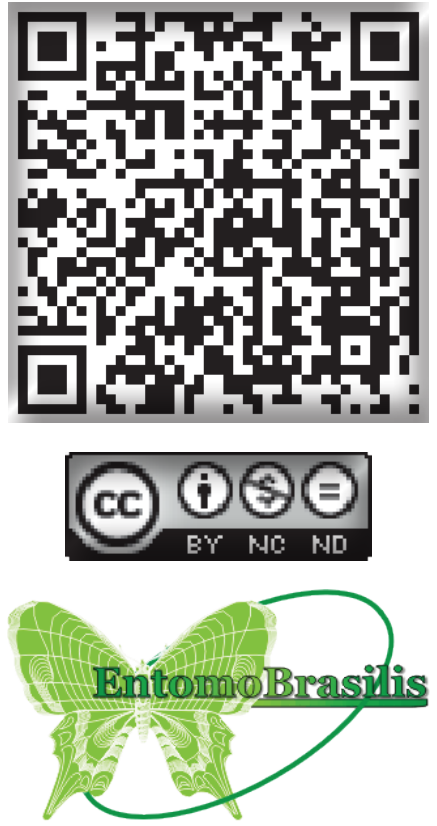

